\title{
Apresentação do debate sobre a Dengue
}

Faz pouco, num Seminário promovido pela FIOCRUZ, - Dr. Fiuza, ex-Superintendente da SUCAM, declarou que o mal da Saúde é "muito discurso e pouco recurso". Quanto à primeira parte, o presente debate foi exemplar, falou-se muito e se disse pouco. Em relação à segunda parte, não estamos perfeitamente de acordo, pois, existe muito desperdício de recursos.

Entre os poucos que falaram e disseram, há que des. tacar o Dr. Pedro Tauil que, sintomaticamente, não pertence aos quadros do Ministério da Saúde.

o que é preciso mencionar, na oportunidade, é que esse episódio da Dengue veio colocar, às claras, o fato do Ministério da Saúde estar, completamente, desprovido de técnicos - um problema que precisa ser atacado com decisão. No entanto, sugerimos, para a sua solução, três alternativas. Uma seria a criação de uma instituição capaz de formar técnicos altamente capacitados, o que não nos parece fácil. A segunda, recrutar técnicos de outras instituições, como tem feito, se bem que em pequena escala, o Instituto Oswaldo Cruz. A terceira, investir, maciçamente. na formação de pessoal, como fez a EMBRAPA e que, hoje, conta com um invejável quadro de pesquisad ores.

No mais, não há muito a destacar. O Dr. Eduardo Costa contou como a Secretaria de Saúde descobriu a epidemia. Os representantes da SUCAM não tinham muito a dizer, porque estavam nos cargos há pouco tempo. As intervenções do público presente estavam cheias de boas intençōes, porém, pouco acrescentaram.

O que deve ser mencionado é que não se chamou. para o debate, nenhum dos sobreviventes do antigo Serviço Nacional de Febre Amarela, que são os homens que sabem matar mosquitos. Quando da in festação do Estado do Pará. pelo Aëdes aegypti, em 1976, eles foram chamados e erradicaram o mosquito do Estado, assim como da área do Maranhão infestada. A nosso ver, no momento, o mais acertado seria entregar a eles, novamente, essa tarefa.

Mario B, Aragäo 